\title{
Carbon flows in a subtidal fine sand community from the western English Channel: a simulation analysis
}

\author{
Pierre Chardy ${ }^{1}$, Jean-Claude Dauvin ${ }^{2}$ \\ ${ }^{1}$ Institut Français de Recherche pour l'Exploitation de la Mer, Centre de Brest, B.P. 70, F-29280 Plouzané, France \\ ${ }^{2}$ M.N.H.N., Laboratoire de Biologie des Invertébrés Marins et Malacologie, 57 rue Cuvier, F-75231 Paris Cedex 05, France
}

\begin{abstract}
Organic carbon flows through the Pierre Noire fine sand community (Bay of Morlaix, France) are described with a trophodynamic point model. Data collected during several annual cycles are used to calibrate the seasonal variations of each benthic compartment. Mean annual values of state variables are correctly simulated. In a first approach, the seasonal varlations were simulated using 2 forcing functions: input of energy and temperature influence. In a second run, spawning and recruitment effects were introduced as regulating factors for the macrobenthic compartments. The resulting annual carbon budget synthesizes the information we have on this common type of ecosystem. Phytoplankton production represents the major food supply to the benthic system and the importance of pelagic-benthic coupling in this area is confirmed. A large proportion of the carbon input is consumed by bacteria which is the main trophic source for meiofauna. Meiofauna is an important link between the bacteria + detritus and the carnivore level, and cannot be considered as an independent food web. The significance of regulation factors such as spawning and recruitment processes in the dynamics of the macrofauna is explored.
\end{abstract}

\section{INTRODUCTION}

Fine sand communities dominated by the bivalve Abra alba are very common in the Northwestern European seas. In the English Channel they are limited to the shallow waters of bays and estuaries, and are usually well separated from other bottom types (rocks, pebbles, gravel and coarse sand). The community of Pierre Noire is dominated by Abra alba and the polychaete Hyalinoecia bilineata and is located in the Bay of Morlaix (western English Channel).

Marine ecosystem modelling has traditionally been dominated by plankton dynamics. Many of the recent investigations in modelling the benthos were developed with generic ecosystem models such as GEMBASE (General Ecosystem Model for the Bristol Channel and the Severn Estuary; Radford 1979), the continental shelf food web simulation analysis (Pace et al. 1984), the Cumberland Basin model (Keizer et al. 1987), and the Ems Estuary model (Baretta \& Ruardij
1988) which represents the most powerful contribution in dynamic modelling of benthic processes. These simulation analyses have provided useful insight into the functioning of the benthic subsystem and its relationships with the pelagic. However, development of benthic submodels is hindered by lack of adequate quantitative information on benthic organisms and on local properties of benthic communities (Silvert 1991). This applies particularly to the lack of continuous series of biomass data for each of the compartments of a benthic community, since such a data base requires substantial field work involving several specialists.

Application of the simulation modelling technique to estimating the carbon flows in the Abra alba community of Pierre Noire was motivated by the availability of a large body of data from field experiments. Qualitative and quantitative data are available from several studies on most of the benthic components: microphytobenthos, bacteria, meiofauna, macrofauna and predation by demersal fishes (Boucher et al. 1984, 
Dauvin 1984, 1988, 1989, 1990, Boucher 1985, Dauvin \& Ibanez 1986, Riaux-Gobin et al. 1989). Detailed observations have been made on seasonal changes of biomass, for dominant species or taxonomic groups which are of particular relevance to food chain dynamics.

These data have here been gathered and applied to a trophodynamic point model. Special attention is paid to the simulation of seasonal changes of the biotic compartment biomasses driven by food supply and temperature. The possible role of other regulator factors as spawning and recruitment in the general dynamics of the benthic system is examined.

The fluxes calculated by the model cannot be directly validated, and as such should be considered with some caution. Where possible, they are compared to literature data to ascertain whether their order of magnitude is consistent with reality. In the present work, the only possible way to assess the consistency of the model results is to determine the correspondence between simulated standing stocks and field values. The credibility of the simulation is estimated first on the average annual biomass, which is the primary type of information, and then on the seasonal variations of each biotic compartment.

\section{MATERIAL AND METHODS}

Study site. The Pierre Noire community covers a well-defined area of about $20 \mathrm{~km}^{2}$ in the eastern part of the Bay of Morlaix, France, at about $20 \mathrm{~m}$ depth (Cabioch 1968) (Fig. 1). The main characteristics of the abiotic and biotic conditions at Pierre Noire have been described by Dauvin (1984). The sediment is fine sand with a median particle size between 140 and $180 \mu \mathrm{m}$ (about $1 \%$ of particles $<63 \mu \mathrm{m}$ ) and a low particulate organic carbon content comprising from 0.10 to $0.40 \%$ of the dry sediment weight. The bottom water temperature varies ordinarily between $8.8^{\circ} \mathrm{C}$ in winter and $15.3{ }^{\circ} \mathrm{C}$ in summer, and salinity between $34.50 \%$ in winter and $35.30 \%$ at the beginning of the autumn.

Model structure. The model is closely related in concept to the food web simulation model developed for the 'Normand-Breton' coarse sand gulf community (Chardy 1987), itself derived from the work of Pace et al. (1984). It is a trophodynamic 'point model' composed of 11 biotic and abiotic compartments. The simulation is restricted to the carbon flows related to benthic secondary production, and is similar to the model of Warwick et al. (1979) of the benthic community of the Lynher estuary (UK). Three pelagic

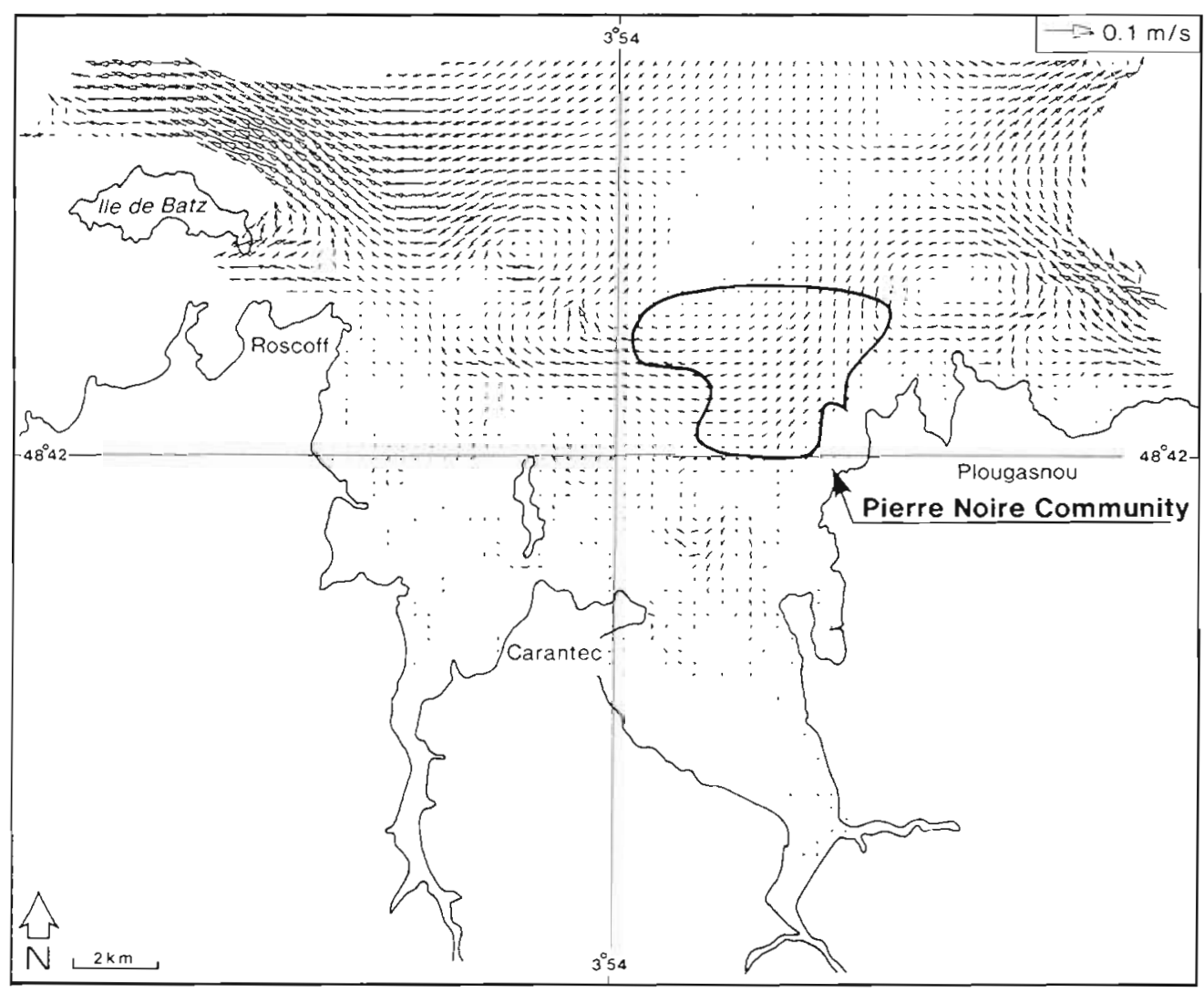

Fig. 1. Residual circulation of water masses in the Bay of Morlaix, from Salomon \& Breton (1987) 
compartments and the microphytobenthos are external variables considered as sources of carbon for the benthic organisms. The state variables are the biomasses of the 7 benthic compartments defined below. All variables are expressed in $\mathrm{g} \mathrm{C} \mathrm{m}^{-2}$. For each state variable, as for the whole benthic system, the sum of inputs equals the sum of outputs, over a period of $1 \mathrm{yr}$ and under steady state conditions

The behaviour of the state variables is described by a set of differential equations of the form:

$$
\mathrm{d} x / \mathrm{d} t=\text { rate of gain }- \text { rate of loss }
$$

Interactions between compartments are modelled using the general equation initiated by Wiegert (1975) and generalized by Pace et al. (1984) (see Appendix 1).

External variables: We used pelagic data obtained by Wafar (1981), Wafar et al. (1983) and Sournia et al. (1987) at Stations 'Bloscon' and 'Astan' located about 4 nautical miles from Pierre Noire in the western part of the Bay of Morlaix where the minimum depth is $25 \mathrm{~m}$.

Y1. Phytoplankton. Monthly chlorophyll a measurements by fluorimetry and primary production estimates using the ${ }^{14} \mathrm{C}$ method were carried out during the period February 1979 to June 1980. Biomass of phytoplankton in carbon units was derived from the conversion C: chl $a=40$ (Steele 1974).

Y2. Zooplankton. Standing stock of zooplankton was based on monthly dry weight measurements, converted to carbon using a conversion coefficient of 0.40 . Zooplankton was collected by vertical hauls with a WP 2 net ( $200 \mu \mathrm{m}$ mesh size).

Y3. Suspended particulate detritus is the allochthonous source of energy for the benthic layer and was estimated from monthly measurements of particulate organic matter (POC) in the water column (CHN autoanalyser). Dead organic matter was estimated by subtracting the amount of carbon in living phytoplankton from measured POC.

Y4. Microphytobenthos. Chloropigment (chl a and phaeopigments) concentrations were measured from sediment cores $\left(5.72 \mathrm{~cm}^{2}\right)$ collected by divers (Boucher et al. 1984) or by a $21 \mathrm{~cm}^{2}$ 'Rouvillois' benthic corer (Riaux-Gobin et al. 1989). A conversion coefficient of C:pigments $=40$ was used to express the standing stock of microphytobenthos in carbon units.

State variables: The biological state variables represent functional groups defined by feeding mode and size criteria.

Benthic field observations were made at the Pierre Noire locality. Nematode and copepod densities were estimated after sieving the sediment on a $40 \mu \mathrm{m}$ mesh; three $5.72 \mathrm{~cm}^{2}$ cores were taken by diver at each sampling (Boucher 1980, 1983, 1985). The densities of the temporary meiofauna (juveniles of macrobenthic species) and of the polychaetes of the permanent meiobenthos were estimated after sieving the sediment on $180 \mu \mathrm{m}$ mesh; five $160 \mathrm{~cm}^{2}$ Reineck cores were taken at each sampling (Dauvin 1989). The densities of the macrobenthic species were estimated after sieving the sediment on a $1 \mathrm{~mm}$ circular mesh; ten $0.1 \mathrm{~m}^{2}$ Smith MacIntyre grabs were taken at each sampling (Dauvin 1984, 1989)

X1. Benthic detritus. Detrital organic matter on/in the sediment layer is a passive, abiotic storage compartment.

X2. Bacteria associated with benthic detritus were estimated from sediment collected by Scuba divers (Boucher et al. 1984). Density was obtained by acridine orange direct count and converted to biomass with a conversion coefficient of $10^{-13} \mathrm{~g} \mathrm{C}$ bacterium $^{-1}$ (Guidi 1981).

X3. Mixed macrobenthic invertebrate species (suspension and surface deposit feeders). The grouping of suspension feeders, deposit feeders and suspension/ deposit feeders proposed by Arntz \& Brunswig (1976) was adopted. These species feed on the organic matter at the sediment surface originating mainly from plankton production and, to a lesser degree, on microphytobenthos and benthic bacteria. This group forms about $25 \%$ of the total biomass of the macrobenthic fauna. It consists of amphipods (e.g. Ampelisca spp.), bivalves (e.g. Abra alba) and numerous species of polychaetes (e.g. Paraonidae, Spionidae) (Table 1).

X4. Subsurface-deposit feeders. These species live in the sediment (e.g. Euclymene oerstedii, Scoloplos armiger; Table 1); their food consists of detritus and bacteria in the sediment. This group represents only $6 \%$ of the total biomass of the macrobenthic species.

X5. Meiofauna. Nematodes, including Richtersia kreisi, Microlaimus conspicuus, Chromaspirina renaudae, Cylindrotheristus divertens and Prochromadorella ditlevseni, are the dominant group of the meiofauna (65 to $86 \%$ of the biomass). Microgastropods (6 to $13 \%$ of the biomass) and harpacticoid copepods (2.5 to $12 \%$ of the biomass) are common. Other meiofauna, including gastrotrichs, halacarids, oligochaetes and turbellarians are rare (Boucher 1980). Polychaetes of the permanent meiofauna (Syllidae, Dorvilleidae) form an important part (about $40 \%$ of the biomass) of the fauna between 0.18 and $1.0 \mathrm{~mm}$. Juveniles of macrobenthic species $(0.18$ to $1.0 \mathrm{~mm})$ are dominated by polychaetes, amphipods and bivalves which represent, respectively, $74 \%, 15 \%$ and $7 \%$ of the total biomass of the temporary meiofauna (Dauvin 1989). Meiofauna and juveniles of macrobenthic invertebrates feed on detritus and bacteria.

X6. Carnivores I. This group consists of motile macrobenthic invertebrate predators, especially the polychaetes Nephtys hombergii, Marphysa bellii, 
Table 1. Biomass of the main species (biomass $>1 \%$ of total macrobenthos in 1986) from the 4 macrobenthic compartments

\begin{tabular}{|lc|}
\hline & $\%$ of total macrofaunal biomass \\
\hline X3. Mixed (suspension and surface-deposit feeders) \\
Ampelisca spp. & 7.5 \\
Polydora pulchra & 5.4 \\
Spio decoratus & 2.7 \\
Ampharete acutifrons & 1.8 \\
Spiophanes bombyx & 1.2 \\
Venus ovata & 1.1 \\
Paraonidae & 1.0 \\
X4. Subsurface-deposit feeders & \\
Euclymene oerstedii & 1.8 \\
Scoloplos armiger & 1.4 \\
X6. Carnivores I & \\
Nephys hombergii & 28.1 \\
Nemertians & 6.1 \\
Marphysa bellii & 3.1 \\
Hyalinoecia bilineata & 1.0 \\
X7. Carnivores Il and omnivores & \\
Nassarius reticulatus & 13.8 \\
Pagurus bernardus & 8.2 \\
Eulalia sanguinea & 1.0 \\
\hline
\end{tabular}

Hyalinoecia bilineata, and nemerteans (Table 1). It forms more than $44 \%$ of the total biomass of the macrobenthic fauna.

X7. Carnivores II. This group is formed by omnivorous (e.g. Eulalia sanguinea) and necrophagous (e.g. Nassarius spp., Pagurus bemardus) invertebrates (Table 1) and demersal fishes (e.g. Trisopterus minutus, Callionymus lyra, Echiichthys vipera). This group represents more than $24 \%$ of the total biomass of the macrobenthic fauna. Stomach content analysis of the 13 main species of demersal fishes showed that they feed on macrobenthic fauna, especially crustacean amphipods; polychaetes and bivalves are only secondary prey (Dauvin 1988)

Limitations: The first theoretical limitation is that all compartments are confined within recognizable spatial boundaries. This is partly acceptable for a spatially well defined benthic unit, as the present Abra alba community, where migratory processes are low. However hydrodynamic transport of the surrounding water is ignored. The required assumption is that pelagic conditions at the boundaries are similar to those within the area, or that exchanges with neighbouring water are weak. These assumptions are not unrealistic if we consider the model of residual circulation established by Salomon \& Breton (1987) in the area (Fig. 1), which exhibits maximum residual currents of $0.02 \mathrm{~m} \mathrm{~s}^{-1}$ at low tide and $0.05 \mathrm{~m} \mathrm{~s}^{-1}$ at high tide. In addition to this argument, the area studied is located within a large coastal zone without any remarkable hydrological discontinuity.
A second limitation (the greater one) is the assumption that biological compartments are homogeneous in terms of feeding mode and individual weight, which is of course far from reality. Despite these limitations, sufficient ecological data have been collected on the community under study to legitimise an attempt to represent carbon flows in the total system coherently.

Forcing functions. In a first run, the model was driven by the energy sources supporting benthic secondary production and temperature. Other regulating factors, such as spawning and recruitment of the macrofauna, were introduced later

Autochthonous source of carbon: This source represents the fraction of primary pelagic production available to the benthos, and benthic primary production. The amount of phytoplankton production reaching the bottom is that portion which is not consumed in the water column. For each day, it was calculated as total primary production less production. of exudates and grazing by zooplankton.

Extracellular products were assumed to be $20 \%$ of daily production. Jones \& Henderson (1987) and Newell et al. (1988) observed that 10 to $30 \%$ of the carbon flow from primary production is channelled to the water column as soluble products.

Grazing of zooplankton on phytoplankton is a function of food concentration, temperature and standing stock of zooplankton. The basic formulation given in Kremer \& Nixon (1978) was used:

$$
G_{I_{i}}=\operatorname{Rmax}_{0} \mathrm{e}^{\left(\alpha t_{1}\right)}-\mathrm{e}^{\left(-k P h y t_{i}\right)} .
$$

where $G r_{1}=$ uptake of phytoplankton on Day $i$ by zooplankton; $\operatorname{Rmax}_{0}=$ Maximum ration of zooplankton at $0^{\circ} \mathrm{C}$ [assumed to be $0.3 \mathrm{~g} \mathrm{C}\left(\mathrm{g} \mathrm{C}^{-1} \mathrm{~d}^{-1}\right.$ ]; $t_{i}=$ temperature on Day $i_{i} \alpha=$ temperature rate constant (assumed to be $=0.069$ ); $k=$ Ivlev constant (assumed to be $=15$, for a phytoplankton concentration expressed in $\mathrm{g}\left(\mathrm{m}^{-3}\right) ;$ Phyt $_{1}=$ phytoplankton concentration on Day $i$.

Faeces production by zooplankton was assumed to be $30 \%$ of food ingestion (Conover 1966), all of which reaches the benthic layer.

In situ primary production by phytobenthos was calculated using a daily production/biomass (P/B) ratio of 0.055 for the standing stock of the upper centimeter of sediment. This resulted in an annual produc. tion of $10 \mathrm{~g} \mathrm{C} \mathrm{m}^{-2}$, which is comparable to the results reported from the Bay of Douarnenez, France (Bodin et al. 1985), where similar conditions exist.

Allochthonous source of carbon: A portion of the detritus suspended in the water column is transfered to the benthic layer. The daily sedimentation rate increases under calm weather conditions and decreases in windy periods. From the trap experiments conducted in the Bay of Morlaix (Dauvin 1984), the sedi- 
mentation rate was assumed to be maximum with a wind of 5 knots and zero over 15 knots.

Temperature: The basic physiological rates used in the biological processes are temperature-dependent with a $Q_{10}$ of 2 . The temperature effect was described by the formulation:

$$
\text { TCOr }_{i}=\mathrm{e}^{0.069 \times\left(t_{i}-12\right)}
$$

where $T_{C_{C} r_{i}}$ the temperature correction factor on Day $i$, is equal to 1 at the annual mean temperature value $\left(12^{\circ} \mathrm{C}\right)$.

\section{Biological processes.}

General assumptions: Interactions between compartments are modelled using the general equations developed by Wiegert (1975), and applied by Pace et al. (1984) and Chardy (1987). For any biological compartment, input is ingestion or uptake, and output is the sum of egestion, respiration, physiological mortality and predation (see Appendix 1). The rate of uptake is controlled by 2 functions which implement the effects of resource limitation and intracompartmental competition (see Appendix 2). For compartments feeding on more than one resource, a feeding preference value was assigned.

Parametrization: Parameter values are presented in Appendix 1. The basic metabolic rates of the different macrofauna compartments were derived from detailed population studies over a period of several years in the Bay of Morlaix (Dauvin 1984, 1991). P/B ratios, which are the basis for the derivation of the physiological parameters, are presented for each macrofaunal compartment in Table 2. For meiofauna and bacteria, only biomass values are available.

For meiofauna, the annual $\mathrm{P} / \mathrm{B}$ ratio was set at 15 , which is intermediate between the value of 9 proposed by Gerlach (1971) and the more recent estimate of 20 by Vranken \& Heip (1986).

For the macrofauna and meiofauna compartments, respiration rate was derived from the empirical relationship established by Schwinghamer et al. (1986):

$$
\log _{10} R_{\mathrm{a}}=0.367+0.993 \log _{10} P_{\mathrm{a}}
$$

where $R_{\mathrm{a}}$ and $P_{\mathrm{a}}=$ annual respiration and production respectively.

Concerning benthic bacteria, annual respiration was assumed to equal annual production. This assumption was adopted by several authors (e.g. Williams 1984, Schwinghamer et al. 1986, Bratbak 1987, Thingstad 1987).

Assimilation efficiency is treated as a constant in the present model. An approximate average of assimilation efficiency was derived from reported values in the literature for the same or related species as those in each compartment. For the 'mixed' compartment, the assimilation efficiency can vary from 25 to
Table 2. Mean annual biomass ( $\mathrm{g} \mathrm{C}^{-2}$ ), production $\left(\mathrm{g} \mathrm{C} \mathrm{m}^{-2}\right.$ $\mathrm{yr}^{-1}$ ) and P/B ratio, derived from Dauvin (1984, 1991). Boucher et al. (1984) and Boucher (1985)

\begin{tabular}{|lccc|}
\hline & Biomass & Production & P/B \\
\hline Mixed & 0.50 & 1.506 & 3.0 \\
Subsurface deposit-feeders & 0.118 & 0.354 & 3.0 \\
Meiofauna & 0.28 & $?$ & $?$ \\
Carnivores I & 0.877 & 1.052 & 1.2 \\
Carnivores Il & 0.482 & 0.723 & 1.5 \\
Bacteria & 0.98 & $?$ & $?$ \\
\hline
\end{tabular}

$75 \%$, depending on the dominant feeding type, which may be suspension or deposit feeding (Widdows \& Bayne 1971, Tenore \& Dunstan 1973, Tenore \& Gopalan 1974, Newell \& Bayne 1980, Dame \& Patten 1981, Navarro \& Winter 1982). An overall assimilation efficiency of $50 \%$ was taken for this group. For deposit-feeders, estimated assimilation values are usually lower. An average efficiency of $20 \%$ for feeding on detritus was derived from the values obtained by Dame \& Patten (1981) and Pace et al. (1984), and a value of $65 \%$ for feeding on bacteria (Hargrave 1970, Tenore et al. 1982).

An estimate of ingestion rate was calculated from the general energy budget $C=P+R+F+U$ (where $C=$ consumption, $P=$ production, $R=$ respiration, and $F=$ faeces) (Crisp 1984). Excretion $(U)$ is considered negligible here in terms of the total carbon flux of the compartments. Taking into account the results of Loo \& Rosenberg (1989) on bivalve suspension-feeding dynamics in Laholm Bay (Kattegat), we consider that annual mean ingestion represents half of the maximum potential feeding capacity. The rate of maximum uptake was deduced from this assumption.

The maximum specific uptake rate of labile organic carbon by benthic bacteria was assumed to be $0.75 \mathrm{~d}^{-1}$, in accordance with the Ems Dollard model assumption from Baretta \& Ruardij (1988).

Non-predatory mortality determines the part of the production which is not assigned to predation, but returns to detritus. Few data are available from the literature on these parameters and they lie between $5 \%$ (Silvestre 1990) and 40\% (Brylinsky 1972). We assumed a mean value of $20 \%$ of annual production for each compartment.

The benthic detritus state variable represents a passive storage of organic carbon. This detrital pool is divided into a labile and a refractory part according to the sources of the detrital material. Only the labile component is utilized by fauna and heterotrophic bacteria. Very few data are available on the precise ratio of the labile to the refractory components of detrital material. The range of values obtained from experiments on bacterial degradation lies between 
$50 \%$ for planktonic phytodetritus (Westrich \& Berner 1984) and < $1 \%$ for marine sediment (Nedwell 1987). Organic carbon coming from the water column has 2 sources: local primary production (including faecal pellets of zooplankton) and allochthonous material. Observations by Iturriaga (1979) in the Baltic Sea indicate that the degradable organic fraction of the particulate organic matter that reaches the sediment is related not only to the production of the upper water layers, but also to transformations that take place during sedimentation. Following Lancelot \& Billen (1985) we assume that the labile fraction of fresh phytoplankton accounts for $50 \%$ of the original material. Assuming that the most labile fraction is consumed in the water column as extracellular products, earlier estimated at $20 \%$ of phytoplankton production, we arrive at $30 \%$ of the phytoplankton detritus reaching the bottom as labile organic carbon. The labile component of allochthonous sedimented material is taken to be $10 \%$, which appears to be high, considering the observations of Grant \& Hargrave (1987) on labile organic carbon in the upper centimeter of coastal sediment from Halifax Harbour (Nova Scotia, Canada). Microphytobenthos production, considered as living material, is partitioned into $50 \%$ labile and $50 \%$ refractory organic carbon.

Control functions: A detailed discussion of these functions is available in Wiegert et al. (1981) (see Appendix 2). The ingestion rate can depend on either the standing stock of the donor or that of the recipient. For each 'donor-recipient' pair, 4 parameters must be included in the control functions which are the thresholds at which food limitation or food saturation occurs. Field and laboratory observations on the values of the thresholds are scarce. In the present study carrying capacity of the system $\left(G_{j j}\right)$ for the recipient compartment is based on the maximum observed biomass in the field. The threshold below which no limitation occurs $\left(A_{j j}\right)$ is derived from the relation $G_{j l}=10 A_{j j}$ (Pace et al. 1984).

Assumptions on donor-density-dependent thresholds are even more artificial, as few data are available. The refuge level $\left(G_{i j}\right)$ is the minimum concentration of donors below which no predation occurs. This value was assumed to be 10 times below the mean observed biomass. The satiation thresholds, under which the ingestion rate of the recipient is maximum, were determined by calibration, assuming that maximum specific predation is a characteristic not only of the predator, but also of the prey population. (Legovic 1989)

Consumers usually feed on more than one food source, so a feeding preference parameter $\left(P_{l, j}\right)$ is included in the ingestion rate control according to the dominant feeding preference, or selection, of each compartment.

\section{RESULTS}

\section{Annual carbon flows and budget}

In the initial run of the model, seasonal forcing functions were (1) inputs of organic carbon from the water column plus microphytobenthic production, and (2) temperature effects on physiological processes. Mean values of biomass and annual fluxes, given in Fig. 2, were obtained after complete stabilization of the system which occured after a number of runs depending on the initial values of the state variables. Agreement with average measured biomass was good (cf. Table 2 \& Fig. 2). At this stage, the results of the simulation provide a rough outline of the community carbon flows.

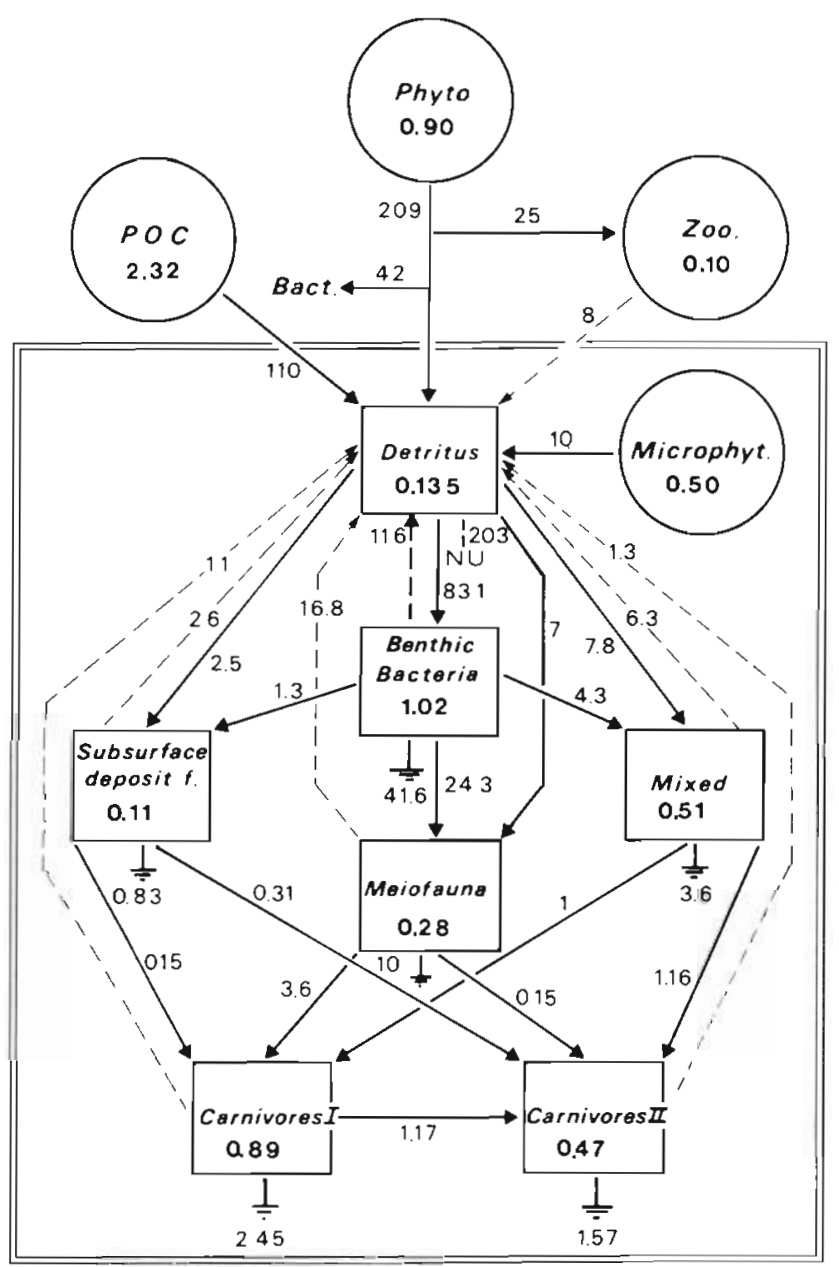

Fig. 2. Annual carbon flows for the Abra alba community: results from the model. Exogeneous variables are in circles; endogeneous variables are in squares $\longrightarrow$ : trophic fluxes; $\longrightarrow$ : faeces + non-predatory mortality; $\overline{\bar{F}}$ : respiration; =: boundary of the benthic system; POC: particulate organic carbon; Phyto.. phytoplankton; Zoo. herbivorous zooplankton; Microphyt: microphytoplankton. NU: not used (stored or exported). Biomasses in $\mathrm{g} \mathrm{C} \mathrm{m}^{-2}$ Annual average flows in $\mathrm{g} \mathrm{C} \mathrm{m}^{-2} \mathrm{y}^{-1}$ 
Phytoplankton production and allochthonous sources of carbon are the 2 main inputs to the benthic system. The annual sedimented phytoplankton biomass is estimated at $53 \%$ of total input, and represents $68 \%$ of pelagic primary production. The simulation shows that much of the phytoplankton primary production is consumed by the benthos and demonstrates the importance of benthic-pelagic coupling Sedimented allochthonous carbon contributes $41 \%$ of the total supply of organic carbon for the benthos, but contributes only $18 \%$ to the labile carbon pool, useful to benthic consumers. Other sources, such as faecal pellets, are negligible.

The annual respiration of benthic heterotrophs in the model is $61 \mathrm{~g} \mathrm{C} \mathrm{m}^{-2} \mathrm{yr}^{-1}, 70 \%$ of which can be attributed to bacteria. Ecological efficiencies (production/ingestion ratio) for benthic fauna vary from 13 to $26 \%$. Annual $\mathrm{P} / \mathrm{B}$ ratios calculated from the output of the model are quite near to those determined in field studies or estimated from the literature: 22.3 for 'bacteria', 14.5 for 'meiofauna', 4 for 'mixed', 4.2 for 'deposit-feeders' and 1.3 for 'carnivores I'.

In the model, the food supply entering the benthic system is mainly utilized by the microbiota (85\%), which itself is largely consumed by the meiofauna $(80 \%)$. The carbon flow diagram clearly shows the central route: [detritus] $\rightarrow$ [microbiota] $\rightarrow$ [meiofauna] which constitutes the major pathway of energy transfer within the benthic system. Conversely, bacteria are not the principal source for macrofauna and contribute about one third of the diets of deposit-feeders and mixed feeders

\section{Seasonal cycle of state variables}

The accuracy of the simulation results in relation to the data is not quantified. The quality of the simulation is judged by visual comparison of measured standing stocks and calculated curves.

Fig. 3 shows seasonal variations in the 6 biotic compartments. The seasonal cycle of bacteria is strongly related to the input of labile organic carbon (Fig. 4) which itself reflects, to a large degree, the pelagic primary production input. The magnitude of the annual variations is quite realistic, but the maximum peak in June appears too early and is overestimated. This discrepancy may be partly explained by the fact that, in the model, phytoplankton production is instantaneously channelled to the benthos, while in the sea, an approximate sedimentation time of $20 \mathrm{~d}$ would be necessary for this transfer.

The meiobenthos compartment follows the dynamics of the bacteria, but with a shift of the biomass peak to the end of the summer period. Field measurements of
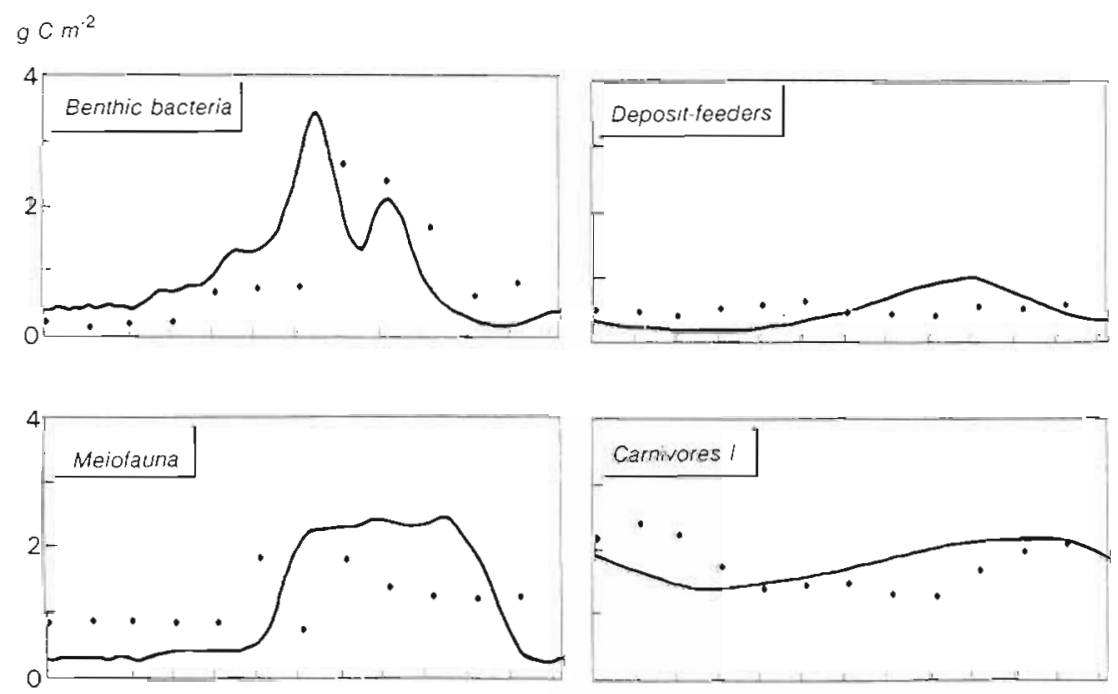

Fig. 3. Simulated biomasses (in $\mathrm{g} \mathrm{C} \mathrm{m}^{-2}$ ) of the benthic compartments over an annual cycle. (•) Observations; ( $(-)$ simulations
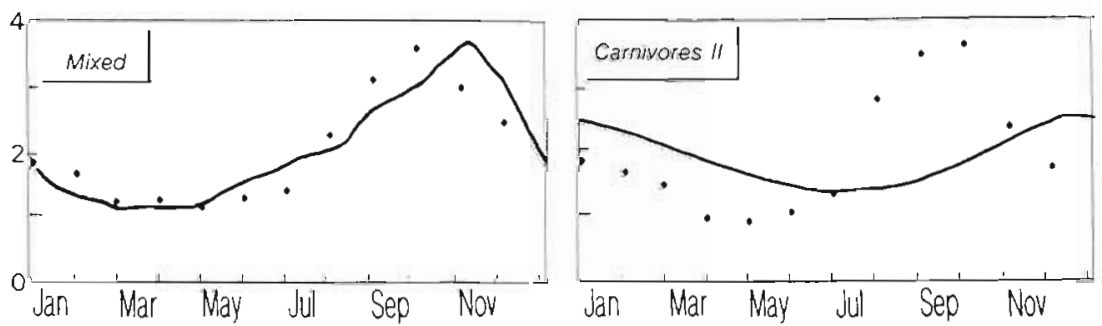


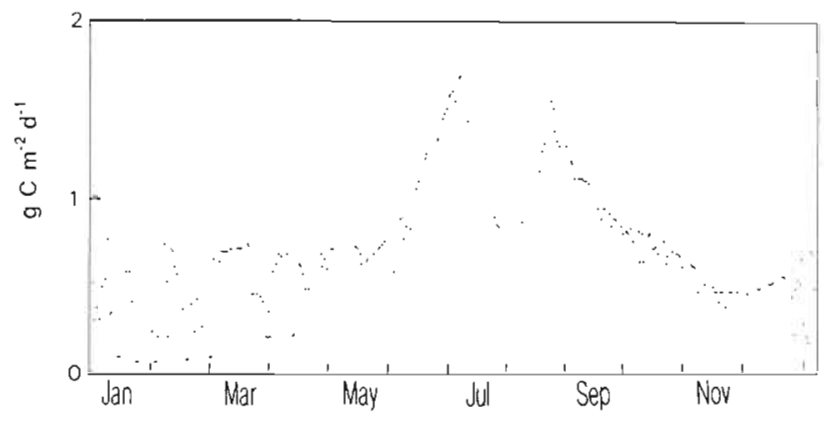

Fig. 4. Simulation of daily net sedimentation of organic carbon in the Bay of Morlaix

the meiofauna compartment exhibit a more complex pattern, with a decline in July, which is not reproduced by the model.

Seasonal changes of the 'mixed' state variables is well simulated, both in amplitude and phase, except for a discrepancy in timing of the maximum biomass. The shape of the seasonal curve is in good accordance with inputs of carbon from the water column and bacterial dynamics, with a slow response time, producing a delay of about 3 mo in the arrival of the maximum biomass

Deposit-feeders show continuously low biomass and no marked seasonal variations. The simulated curve exhibits the same general trend as the 'mixed' compartment, the feeding sources being the same. Field measurements confirm the lack of a maximum biomass in September.

Carnivores I and II are not adequately simulated, seasonal variations being out of phase and with damped amplitude. Food availability and temperature factors are insufficient to simulate the dynamics of the higher trophic levels of the benthic food web which may be affected by other regulating factors such as spawning and recruitment.

\section{Spawning and recruitment effects}

Spawning and recruitment effects can be introduced in the simulation insofar as knowledge of the life cycle of the major populations of the macrofauna compartments is available. Periods of spawning and recruitment were derived from studies by Dauvin (1984, 1990). The spawning function drives the release of the amount of energy equivalent to the annual gonad production in daily portions over the spawning period (see function SPAWN; Appendix 3). Gonad production is estimated at $20 \%$ of annual somatic production (Admiraal et al. 1988). The energy released is transferred to the pelagic system and is considered as an output.
Recruitment effects are more complex to simulate. Settlement of larvae makes a very small contribution to biomass (Admiraal et al. 1988), but significantly modifies the mean individual weight of the compartment. Basic metabolic rates, as exponential functions of individual weight, therefore are strongly affected. This is illustrated by examination of the size frequency distribution of the Abra alba population in 1980 (Dauvin 1984). The variation of the $P / B$ ratio was approximated using the function defined by Schwinghamer et al. (1986): $\mathrm{P} / \mathrm{B}=0.525 W_{\mathrm{i}}^{-0.304}$ (Fig. 5), mean individual weight $\left(W_{1}\right)$ being derived from a lengthweight allometric relationship. The $P / B$ ratio varies between 0.4 and 4 during an annual cycle. From these observations we can expect that the recruitment effect may be an important regulator mechanism of standing stock fluctuations.

Recruitment was simulated by increasing the basic ingestion and respiration rates of the macrofauna compartments by a factor of 2 when the mean individual weight is considered to be minimum (see function RECRUITMENT; Appendix 3). The other parameters, established for the first standard run, were not modified. Larval settlement is neglected in the model.

Introducing spawning and recruitment effects into the model does not affect the results for microbiota, meiofauna, and mixed and subsurface deposit-feeders (Fig. 6). There is good agreement between observed data and model results for carnivores I from April to December, the period during which spawning and recruitment occur (Fig. 6). But the model still does not correctly simulate standing stock variations during the first 4 mo of the year. A possible explanation is that some species within the compartment are, in reality, able to use detritus from the water column, and are not strictly carnivorous as modelled. A change of feeding habits can also occur between juveniles (detrivorous) and adults (strictly carnivorous), as in Nephtys hombergii.

Simulation of carnivores II is partly corrected in the second part of the year compared to the first analysis,

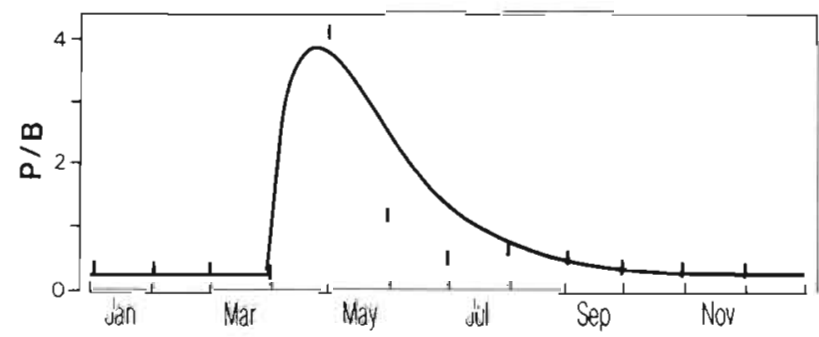

Fig. 5. Calculated production/biomass (P/B) ratio (points) over an annual cycle using the function of Schwinghamer et al. (1988), with adjusted line: $\mathrm{P} / \mathrm{B}=0.525 W_{1}^{-0.304}$ (where $W_{1}=$ mean individual weight) 

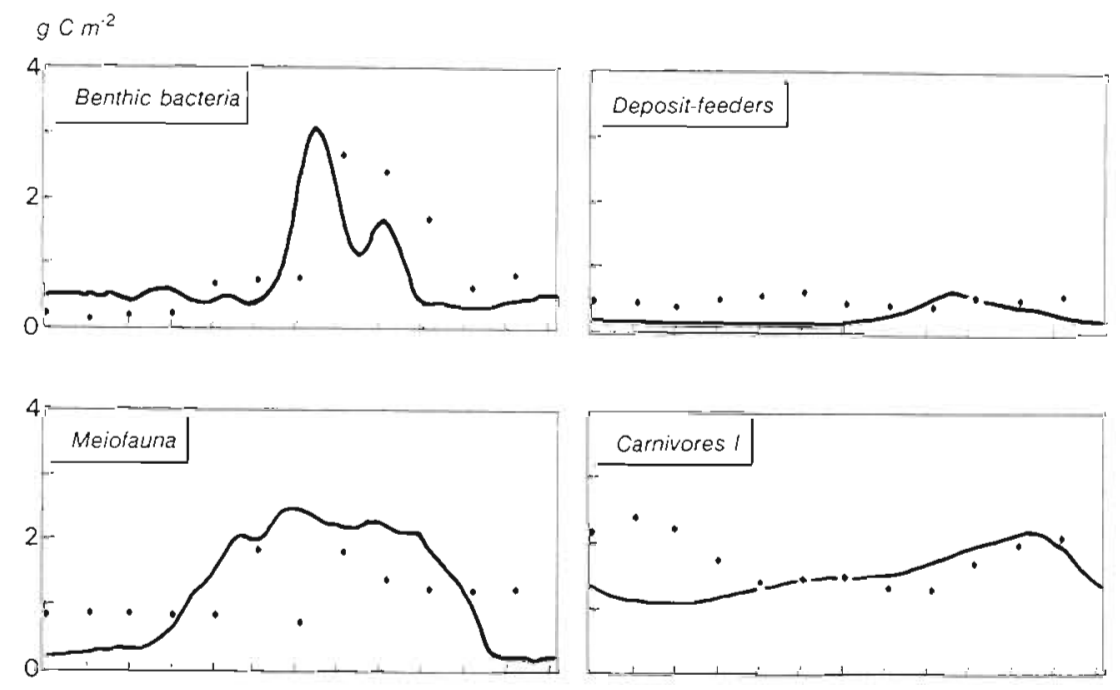

Fig. 6. Simulated biomasses (in $\mathrm{g} \mathrm{C} \mathrm{m}^{-2}$ ) of the benthic compartments over an annual cycle after introduction of spawning and recruitment effects. (•) Observations; $(-)$ simulations
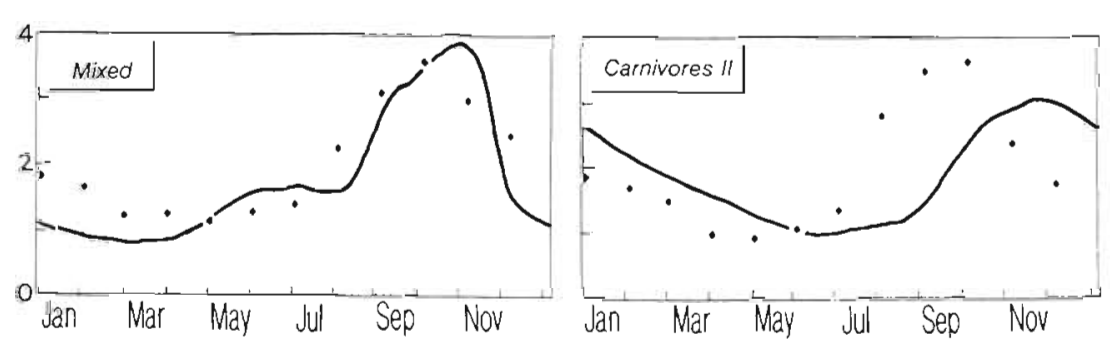

but the simulated maximum of biomass is almost 2 mo later than in field observations. This reflects a strong 'predator-prey' link with carnivores I, which represents, in the model, the main trophic source for carnivores II. This link is probably much too rigid, and more diverse feeding by carnivores Il would reduce the lag of the maximum biomass in the model.

\section{Sensitivity analysis}

In order to ascertain which physiological parameters have a large influence on the results, a sensitivity analysis was performed by running the model with different values of parameters. The results are illustrated in Table 3 which shows the relative sensitivity of each compartment to an increase of $10 \%$ of the value of each physiological rate. For example, an increase of $10 \%$ in ' $\mathrm{I}_{2}$ ', the maximum rate of consumption of bacteria, produces an increase of biomass of the compartments 'bacteria', 'deposit-feeders' and 'carnivores I' compartments, and a decrease of the compartments 'mixed', 'meiofauna' and 'carnivores II'. The sum of absolute values of the relative changes expresses the 'total change' (Brylinsky 1972) and defines the most sensitive parameters. In view of the wide variability of almost all reported parameter values in the literature, an increase of $10 \%$ is a minor change; nevertheless it gives an idea of the relative influence of the physiological rate on the output state variable. Mortality is not a sensitive parameter. Highest total changes are caused by increasing maximum ingestion rate of the 'mixed' and 'meiofauna' compartments, carbon conversion efficiency of the 'bacteria' compartment, and egestion rate of the 'mixed' compartment. This analysis shows the highest relative sensitivities to the parameters driving the carbon flow through 'bacteria' and 'meiofauna' compartments, through which the transfer of energy is the greatest. These changes illustrate the trophic competitive relationships between the compartments, particularly between 'mixed', 'depositfeeders' and 'meiofauna', at one level, and 'carnivores I' and 'carnivores II', at a second level.

\section{DISCUSSION}

A general view of the annual carbon budget of the Abra alba community of the Bay of Morlaix indicates that phytoplankton production is the largest organic carbon source for the benthos and that $68 \%$ of the primary production is consumed by the benthos. This estimate is similar to observations made in the Abra alba community of the western Baltic, where $61 \%$ of the pelagic production was found to reach the sea-floor (Arntz 1978). Previous studies in shallow water have 
Table 3. Results of the sensitivity analysis. Relative sensitivity in percent change of biomass to an increase of $10 \%$ of parameter values. Total change is the sum of the absolute values of the relative changes. For explanation of parameters, see Appendix 1

\begin{tabular}{|c|c|c|c|c|c|c|c|}
\hline Parameter & $\begin{array}{c}\mathrm{X} 2 \\
\text { Bacteria }\end{array}$ & $\begin{array}{c}\text { X3 } \\
\text { Mixed }\end{array}$ & $\begin{array}{c}\mathrm{X} 4 \\
\text { Deposit }\end{array}$ & $\begin{array}{c}\mathrm{X} 5 \\
\text { Meiofauna }\end{array}$ & $\begin{array}{c}\mathrm{X} 6 \\
\text { Carnivores I }\end{array}$ & $\frac{X^{7}}{\text { Carnivores II }}$ & $\begin{array}{l}\text { Total } \\
\text { change }\end{array}$ \\
\hline $\mathrm{I}_{2}$ & 9.25 & -10.65 & 7.96 & -5.96 & 0.79 & -13.68 & 48.30 \\
\hline $\mathrm{I}_{3}$ & -28.54 & 50.89 & -40.71 & 16.84 & -4.17 & 42.95 & 184.10 \\
\hline $\mathrm{I}_{4}$ & -14.67 & 8.68 & 8.85 & 9.12 & -1.24 & 12.18 & 54.73 \\
\hline $\mathrm{l}_{5}$ & -28.15 & 8.68 & -33.63 & 28.42 & -0.34 & 20.73 & 116.94 \\
\hline$I_{6}$ & 9.35 & -5.72 & 7.08 & -5.61 & 3.83 & -8.76 & 40.35 \\
\hline $\mathrm{I}_{7}$ & -15.75 & -6.71 & -23.01 & 15.79 & -4.73 & 3.42 & 69.40 \\
\hline $\mathrm{R}_{2}$ & -40.65 & 9.66 & -46.02 & 14.74 & -4.39 & 10.04 & 125.50 \\
\hline $\mathrm{R}_{3}$ & 15.55 & -19.53 & 15.04 & -6.67 & 2.93 & -23.29 & 83.01 \\
\hline $\mathrm{R}_{4}$ & 1.28 & 0.59 & -10.62 & 0.00 & 0.90 & -7.05 & 20.44 \\
\hline$R_{S}$ & 0.59 & 5.33 & 1.77 & -7.02 & -1.69 & -7.69 & 24.08 \\
\hline $\mathrm{R}_{6}$ & -2.17 & 4.54 & 0.88 & 0.35 & -2.14 & -6.62 & 16.70 \\
\hline$R_{7}$ & -7.58 & 17.16 & 0.88 & 2.46 & 2.70 & -6.84 & 37.62 \\
\hline $\mathrm{M}_{2}$ & -14.17 & 7.89 & -9.73 & 7.37 & -1.46 & 7.48 & 48.11 \\
\hline $\mathrm{M}_{3}$ & 1.18 & -1.78 & 0.88 & -0.35 & 0.23 & -1.92 & 6.34 \\
\hline$M_{4}$ & 0.20 & -0.20 & -0.88 & 0.00 & 0.00 & -0.43 & 1.71 \\
\hline$M_{S}$ & 0.49 & 0.00 & 0.00 & -0.70 & -0.23 & -0.64 & 2.06 \\
\hline$M_{6}$ & 0.00 & 0.00 & 0.00 & 0.00 & -0.23 & -0.21 & 0.44 \\
\hline$M_{7}$ & -0.30 & 0.59 & 0.00 & 0.35 & 0.11 & -0.43 & 1.78 \\
\hline$E_{3}$ & 24.61 & -29.78 & 23.01 & -9.12 & 4.05 & -32.05 & 122.63 \\
\hline$E_{4}$ & 5.51 & -4.54 & -14.16 & -1.75 & -0.11 & -5.56 & 31.63 \\
\hline$E_{4 b}$ & -0.79 & 2.56 & -5.31 & 0.70 & 0.90 & -4.27 & 14.54 \\
\hline$E_{5}$ & 15.94 & 0.99 & 11.50 & -14.39 & -5.29 & -9.83 & 57.94 \\
\hline$E_{6}$ & -2.85 & 2.76 & -1.77 & 1.75 & -1.58 & 0.43 & 11.14 \\
\hline $\mathrm{E}_{7}$ & -1.87 & 3.75 & 0.00 & 0.70 & 0.68 & -1.92 & 8.92 \\
\hline
\end{tabular}

shown that the part of primary production sinking to the bottom ranges from 25 to $60 \%$ (Zeitzschel 1979). Thus, strong benthic-pelagic coupling could be an important feature of the carbon budget of the Abra alba community.

In terms of total organic carbon, allochthonous matter constitutes a significant input ( $41 \%$ of the total) which is in agreement with most of the budgets established in coastal areas such as the Wadden Sea or Ems-Dollard estuary (Kuipers et al. 1981, De Wilde \& Beukema 1984, Baretta \& Ruardij 1988). But the contribution of this source as a food supply, which assumes a distinction, at least, between labile and refractory carbon, is rarely outlined in carbon flow studies.

The overall annual consumption of the benthic heterotrophic compartment ( $\left.61 \mathrm{~g} \mathrm{C} \mathrm{m}^{-2} \mathrm{yr}^{-1}\right)$ is in good agreement with estimates for other subtidal areas such as the Fladen Ground of the North Sea $(50$ to $70 \mathrm{~g} \mathrm{C}$ $\mathrm{m}^{-2} \mathrm{yr}^{-1}$; De Wilde et al. 1986) and the continental shelf of New England, USA $\left(48 \mathrm{~g} \mathrm{C} \mathrm{m}^{-2} \mathrm{yr}^{-1}\right.$; Rowe et al. 1988). It is considerably higher than the results of De Wilde et al. (1984) for the Oyster Ground, North Sea (28 $\mathrm{g} \mathrm{C} \mathrm{m}^{-2} \mathrm{yr}^{-1}$ ) and lower than Baretta \& Ruardji's (1988) estimate from the model of the western Wadden Sea $\left(192 \mathrm{~g} \mathrm{C} \mathrm{m}^{-2} \mathrm{yr}^{-1}\right)$
The total heterotrophic benthic biomass of the Pierre Noire fine sand community is $3.28 \mathrm{~g} \mathrm{C} \mathrm{m}^{-2}$. This value is lower than the biomass of $8.1 \mathrm{~g} \mathrm{C} \mathrm{m}^{-2}$ measured by Warwick et al. (1979) on a mud-flat in the Lynher estuary (Cornwall, UK) where Nepthys hombergii is dominant or the estimate of $6.6 \mathrm{~g} \mathrm{C} \mathrm{m}^{-2}$ in an Abra alba community of the North Sea by Gerlach (1978), but similar to the biomass of 2 to $4 \mathrm{~g} \mathrm{C} \mathrm{m}^{-2}$ measured by Rees (1983) at some stations of Abra alba/Venus striatula along the North Sea coast of Yorkshire, UK. The pecularity of the Pierre Noire community trophic structure is that the top consumers of the food web, which are the carnivorous compartments, represent $42 \%$ of the total heterotrophic biomass. This property has strong implications on the contribution of microbiota and meiofauna to the general features of carbon flow.

Regarding the role of particulate organic matter in benthic nutrition, Levinton et al. (1984) noted 'it is likely that a complex answer to the detritus-microbesbenthos nutrition problem will emerge'. The contribution of the bacteria to the fluxes in benthic food webs is still poorly known. Estimation of bacterial production in the sediment is a way to determine such a contribution (Van Duyl \& Kop 1990). The mean production value estimated from the model $\left(116 \mathrm{mg} \mathrm{C} \mathrm{m}^{-2} \mathrm{~d}^{-1}\right)$ is 
of the same order of magnitude as field results from comparable subtidal ecosystems: 30 to $390 \mathrm{mg} \mathrm{C} \mathrm{m}^{-2}$ $\mathrm{d}^{-1}$ in the Dutch Wadden Sea (Van Duyl \& Kop 1990), 100 to $810 \mathrm{mg} \mathrm{C} \mathrm{m}^{-2} \mathrm{~d}^{-1}$ in a coastal zone off Georgia, USA (Fallon et al. 1983) and $43 \mathrm{mg} \mathrm{C} \mathrm{m}^{-2} \mathrm{~d}^{-1}$ in a coastal zone of Germany (Meyer-Reil et al. 1980). These values suggest that bacteria are a significant trophic link between detritus and benthic organisms. Data on the seasonal variation of bacterial biomass in temperate subtidal sediment are very scarce. However, the simulation gives a range between 0.2 and $4.8 \mathrm{~g} \mathrm{C} \mathrm{m}^{-2}$ which is in good agreement with bacterial biomass variations measured in the top $5 \mathrm{~cm}$ in a shallow marine bay of the northern Adriatic Sea (Herndl et al. 1987). The link between the variation of organic carbon input and seasonal pattern of bacterial biomass supports the idea that benthic microbiota is limited by the supply of organic material, most of which comes from the water column via sedimentation (Meyer-Reil 1987, Billen \& Lancelot 1988, Cole et al. 1988, Van Duyl \& Kop 1990). The partitioning of the available detritus among benthic bacteria, meiofauna and macrofauna is dependent on the response time of each compartment to changes in food supply (Baretta \& Ruardji 1988). The microbiota, having the shortest generation time and fastest response, consumes $84 \%$ of the detritus. The role of meiobenthos as potential food for macrofauna is still a matter of research today. The concept of an 'independent food web with a low predation pressure' (Banse \& Mosher 1980) has been supported by several authors. McIntyre et al. (1970) and Gerlach (1971) hold that meiobenthos represents a supplementary, but not essential, food source for the macrobenthos, mostly for subsurface deposit-feeders, in accordance with the lack of selectivity of their nutritional mode. The general picture of the carbon flows throught the Abra alba community of the Bay of Morlaix, exhibited by the model, does not support this view. The existence of the 'upper part' of the food web is strongly linked to meiofauna production. In their review of the productivity of marine nematodes, Vranken \& Heip (1986) outline examples of fish and crustacean diets in which the meiofauna component is well represented. The main argument in favour of the importance of meiofauna as an important link between bacteria/detritus and carnivores in our model is the low biomass of the deposit-feeders and suspension feeders, whose production is insufficient to support the energy demand of the top consumers.

Seasonal variations of the benthic compartment are satisfactorily simulated at low trophic levels, except for the meiobenthos which is probably contains most complex mix of feeding modes. Discrepancies between the simulation and field data are large in the 'upper part' of the benthic food web due to limitations in the model. One limitation is that carnivorous diet is probably more flexible and opportunistic than in our theoretical representation of the food web. The Lynher model (Warwick et al. (1979) clearly illustrates that Nephtys hombergii is incapable of surviving as a strict predator. Their most realistic simulation has been achieved by allowing Nephtys to feed on phytobenthos as well as meiofauna and deposit feeders. Possible adaptative changes in the diet might occur according to the availability of the food source supplies. Another important limitation in our model is that the dynamics of carnivores, which are composed of long-lived species, cannot be described only by 'growth-related' processes formulated by a set of 'donor-recipient' functions. Even a rough simulation of the spawning and recruitment processes improves the results. Time of spawning may be partly driven by temperature, but at this state of our knowledge, we cannot derive a predictive function of recruitment from a simple formulation. The success of recruitment is dependent on a complex of factors (hydrodynamics, food, temperature, juvenile mortality, larval fixation, etc.) and is still a central problem of population dynamics (Dauvin 1989, 1990).

\section{CONCLUSION}

Any carbon flow investigations dealing with benthic ecosystems encounter the same major elements: sources of organic matter, significance of the bacteria as a trophic source, importance of the meiofauna to higher trophic levels, competition among macrofauna consumers, efficiencies of the energy transfers, etc.

In summary, carbon flow pathways within the Abra alba community of the Bay of Morlaix have the following main features:

(1) Phytoplankton production represents the major food supply for the benthic system and confirms the importance of the pelagic-benthic coupling in such an area.

(2) A large proportion of the carbon input is consumed by the bacteria $(84 \%)$, which itself constitutes the main trophic source $(80 \%)$ for the meiofauna. The microbiota is not the most important diet for mixed and deposit-feeders, which mainly consume sedimented detritus.

(3) Meiofauna is an important trophic link between the basic food supply (bacteria + detritus) and the carnivore level, and cannot be considered as an independent food web.

(4) Efficiencies of energy transfer range from 13 to $26 \%$, which is in accordance with the mean values encountered in similar ecosystems.

Dynamics of the benthic compartments formulated by growth-related processes are unrealistic in the 
higher trophic levels of the food web. Two main reasons are: the lack of realism in the modelled diet of the carnivores, which might feed more opportunistically, and the lack of regulation factors such as spawning and recruitment.

Taking into consideration spawning and recruitment effects, as forcing functions in the model, improves the agreement with the observations for the carnivore compartments. Thus, spawning and recruitment may be considered important regulating factors. Modelling these processes, however, requires detailed population studies and cannot be based on simple formulations because of the diversity and complexity of the factors involved.

Acknowledgements. This study was carried out under the CNRS programme 'GDR Manche' The authors thank captain and crew of the NO 'Mysis', and staff of the Station Biologique de Roscoff, for their valuable assistance in the field work. $M$. Joncourt for his help in estimating the macrofauna biomasses and $\mathrm{C}$. Coriou for typing the manuscript. We gratefully acknowledge Dr R. M. Warwick for his critical reading and helpful comments on the manuscript.

\section{APPENDIX 1}

General equation used for simulation of interactions between biotic compartments (from Pace et al. 1984):

$$
\frac{\mathrm{d} X_{j}}{\mathrm{~d} t}=\sum_{i=1}^{m}\left(P_{i j} I_{j} \cdot X_{j} \cdot F_{j j} \cdot F_{i j} \cdot\left(1-E_{j}\right)-\left(M_{j}+R_{j}\right) \cdot X_{j}\right)-\sum_{k=1}^{n}\left(P_{j k} \cdot I_{k} \cdot X_{k} \cdot F_{j k} \cdot F_{k k}\right)
$$

where $X_{j}=$ biomass of compartment $j_{i} I_{j}=$ maximum specific rate of ingestion of $j_{i} P_{i j}=$ feeding preference for a resource $i$ by $j_{i}$ $F_{i j}=$ limitation on ingestion of $j$ by the scarcity of the resource $i$ (see Appendix 2, Control functions); $F_{\mu l}=$ Limitation on ingestion of $j$ by intracompartmental competition (see Appendix 2 , Control functions) $E_{j}=$ proportion of ingestion which is egested; $M_{j}=$ non-predatory mortality rate $R_{j}=$ respiration rate $i(=1 \ldots \mathrm{m})=$ available resources for $j ; k(=1 \ldots n)=$ predators for $j$.

Differential equations for each of the 6 biotic compartments are written employing the general format of Eq. (1). Values of biotic compartment rates are given in Table A1.

Table A1. Values of biotic compartment rates used in the model. All values are $\mathrm{d}^{-1}$ except egestion which is dimensionless

\begin{tabular}{|c|c|c|c|c|c|}
\hline Compartments & & $\begin{array}{c}\text { Ingestion } \\
I_{i}\end{array}$ & $\begin{array}{c}\text { Respiration } \\
R_{i}\end{array}$ & $\begin{array}{c}\text { Mortality } \\
M_{1}\end{array}$ & $\begin{array}{c}\text { Egestion } \\
E_{1}\end{array}$ \\
\hline Benthic bacteria & $x_{2}$ & 0.75 & & 0.030 & \\
\hline Mixed & $x_{3}$ & 0.09 & 0.19 & 0.0014 & 0.50 \\
\hline Deposit-feeders & $\mathrm{X}_{4}$ & 0.12 & 0.019 & 0.0015 & $0.80-0.35^{\mathrm{c}}$ \\
\hline Meiofauna & $x_{5}$ & 0.54 & 0.095 & 0.010 & 0.50 \\
\hline Carnivores I & $X_{6}$ & 0.026 & 0.0075 & 0.0005 & 0.20 \\
\hline Carnivores II & $x_{7}$ & 0.034 & 0.0094 & $0.0040^{\mathrm{b}}$ & 0.20 \\
\hline
\end{tabular}

\section{APPENDIX 2}

\section{Control functions (from Wiegert et al. 1981)}

Control by scarcity of a resource, or donor:

$$
F_{\mu}=1-\frac{\left(A_{i j}-X_{j}\right)}{\left(A_{i j}-G_{i j}\right)}
$$

where $X_{i}=$ biomass of the donor compartment $i_{;} A_{i j}=$ satiation threshold of $i$ : if $X_{j}>A_{i j}$ then $F_{i j}=1 ; G_{i j}=$ threshold biomass below which the specific ingestion rate of the recipient compartment $j$ is zero (refuge level): if $X_{1}<G_{i j}$, then $F_{l j}=0$.

Control by intracompartmental competition:

$$
F_{\mu l}=1-1-\left(\frac{\left(R_{j}+M_{j}\right)}{I_{j}\left(1-E_{j}\right)}\right)\left(\frac{\left(X_{j}-A_{j}\right)}{\left(G_{j}-A_{j j}\right)}\right)
$$

where $X_{j}=$ biomass of the compartment $j_{i} A_{i j}=$ threshold biomass below which the specific ingestion rate of $j$ is maximal: if $X_{j}<A_{j}$, then $F_{j}=1 ; G_{j}=$ threshold biomass above which the specific ingestion rate of $j$ is equal to maintenance:

if $X_{j}>G_{j,}$ then $F_{j j}=\frac{\left(R_{j}+M_{j}\right)}{I_{j}\left(1-E_{j}\right)}$

Threshold values are given in Tables A2 \& A3. 
Table A2. Values of the resource thresholds $\left(A_{i j}, G_{i l}\right)$ and feeding preferences $\left(P_{11}\right)$ of the trophic fluxes $\left(F_{11}\right)$

\begin{tabular}{|c|c|c|c|c|c|c|}
\hline Flux $\left(F_{n j}\right)$ & $A_{i}$ & $G_{i j}$ & $P_{1 j}$ & & & \\
\hline$F_{12}$ & 0.40 & 0.01 & & Compartment & $A_{11}$ & $G_{j}$ \\
\hline$F_{13}$ & 0.20 & 0.02 & 0.60 & & & \\
\hline$F_{14}$ & 0.20 & 0.02 & 0.70 & $X_{2}$ & 0.50 & 5.00 \\
\hline$F_{15}$ & 0.20 & 0.02 & 0.30 & & & \\
\hline$F_{23}$ & 1.20 & 0.10 & 0.40 & $x_{3}$ & 0.40 & 4.00 \\
\hline$F_{24}$ & 1.00 & 0.10 & 0.30 & & & \\
\hline$F_{25}$ & 0.50 & 0.01 & 0.70 & $x_{4}$ & 0.05 & 0.50 \\
\hline$F_{36}$ & 0.40 & 0.32 & 0.20 & & & \\
\hline$F_{46}$ & 0.40 & 0.12 & 0.20 & $X_{5}$ & 0.07 & 0.70 \\
\hline$F_{56}$ & 0.10 & 0.03 & 0.60 & & & \\
\hline$F_{37}$ & 0.80 & 0.05 & 0.30 & $X_{6}$ & 0.15 & 1.50 \\
\hline$F_{47}$ & 0.35 & 0.01 & 0.30 & & & \\
\hline$F_{57}$ & 0.80 & 0.03 & 0.10 & $X_{7}$ & 0.13 & 1.13 \\
\hline$F_{67}$ & 1.40 & 0.09 & 0.30 & & & \\
\hline
\end{tabular}

\section{APPENDIX 3}

\section{Function SPAWN:}

$y_{j}=a_{1}-b_{1} \cos \left(2\left(j-c_{1}\right) / 365\right)$ (if $y_{l}<0$ then $\left.y_{3}=0\right)$

where $y_{j}=$ daily biomass released; $a_{1}=$ parameter controlling the spreading of the spawning period; $b_{1}=$ parameter controlling the quantity of biomass released; $c_{1}=$ parameter controlling the period of the maximum spawning peak; $j=$ day of the year.

\section{Function RECRUITMENT:}

$f_{j}=a_{2}-b_{2} \cos \left(2\left(j-c_{2}\right) / 365\right)\left(\right.$ if $f_{j}<1$ then $\left.f_{j}=1\right)$

where $f_{1}=$ corrective factor for the physiological rates; $a_{2}=$ parameter controlling the spreading of the recruitment period; $b_{2}=$ parameter controlling the intensity of $t_{j} ; c_{2}=$ parameter controlling the period of the maximum recruitment peak; $j=$ day of the year

\section{LITERATURE CITED}

Admiraal, W., Van Arkel, M. A., Baretta, J. W., Colijn, F., Ebenhöh, W., De Jonge, V N., Kop, A., Ruardij, P., Schroder, H. G. J. (1988). The construction of the benthic submodel. In: Baretta, J. W., Ruardij, P. (eds.) Tidal flat estuaries. Simulation and analysis of the Ems estuary. Springer, Berlin, p. 105-152

Arntz, W. E. (1978). The 'upper part' of the benthic food web: the role of macrobenthos in the western Baltic. Rapp. P.-v. Réun. Cons. int. Explor. Mer. 173: 85-100

Arntz, W. E., Brunswig, D. (1976). Studies on structure and dynamics of macrobenthos in the Western Baltic carried out by the joint research programme 'Interaction sea-sea bottom' (SBF 95 - Kiel). In: Persoone, G., Jaspers, E. (eds.) Proc. 10th Eur. Mar. Biol. Symp. Universa Press, Wetteren, p. $17-42$

Banse, K., Mosher, S. (1980). Adult body mass and annual production/biomass relationships of field populations Ecol. Monogr. 50: 375-379

Baretta, J. W. Ruardij, P. (1988). Carbon flows in the western Wadden Sea: model calculations. Scient. mar. 53: 523-529

Billen, G., Lancelot, C., (1988). Modelling benthic nitrogen cycling in temperate coastal ecosystems. In: Blackburn, T $\mathrm{H}$., Sorensen, J. (eds.) Nitrogen cycling in coastal marine environments, John Wiley and Sons Ltd., New York, p. $341-378$

Bodin, P., Boucher, D., Guillou, J., Guillou, M. (1985). The trophic system of the benthic communities in the bay of Douarnenez (Brittany). In: Gibbs, P. E. (ed.) Proc. 19th Eur
Mar. Biol. Symp. Cambridge University Press, Cambridge, p. $361-370$

Boucher, G. (1980). Impact of Amoco Cadiz oil spill on intertidal and sublittoral meiofauna. Mar. Pollut. Bull. 11 95-100

Boucher, G. (1983). Evolution du peuplement de méiobenthos des sables fins sublittoraux de la baie de Morlaix. In Boutler, J. (ed.) Proc. Eur. Mar. Biol. Symp. Oceanol. Acta vol. spéc., p. 33-37

Boucher, G. (1985). Long term monitoring of meiofauna densities after the Amoco Cadiz oil spill. Mar. Pollut. Bull. 16: $328-333$

Boucher, G., Chamroux, S., Riaux, C. (1984). Modifications des caractéristiques physicochimiques et biologiques d'un sable sublittoral pollué par hydrocarbure. Mar. environ. Res. 12: 1-23

Bratbak, G. (1987). Carbon flow in an experimental microbial ecosystem. Mar. Ecol. Prog. Ser. 36: 267-276

Brylinsky, M. (1972). Steady-state sensitivity analysis of energy flow in a marine system. In: Patten, B. C. (ed.) System analysis and simulation in ecology. Academic Press, New York, p. 81-101.

Cabioch, L. (1968). Contribution à la connaissance des peuplements benthiques de la Manche occidentale. Cah. Biol. mar. 9: 493-720

Chardy, P. (1987). Modèle de simulation du système benthique des sédiments grossiers du golfe normandbreton (Manche). Oceanol. Acta 10:421-434

Cole, J. J., Findlay, S., Pace, J. L. (1988). Bacterial production in fresh and salt water ecosystems: a cross-system over- 
view. Mar. Ecol. Prog. Ser. 43: 1-10

Conover, R. J. (1966). Assimilation of organic matter by zooplankton. Limnol. Oceanogr. 11: 338-345

Crisp, D. J (1984). Energy flow measurements. In: Holmes, Mc Intyre (eds.) Methods for the study of marine benthos. I.B.P. Handbook. Blackwell Scientific Publications, Oxford, p. 284-372

Dame, R. F., Patten, B. (1981). Analysis of energy flow in an intertidal oyster reef. Mar. Ecol. Prog. Ser. 5: 115-124

Dauvin, J. C. (1984). Dynamique d'écosystèmes macrobenthiques des fonds sédimentaires de la Baie de Morlaix et leur perturbation par les hydrocarbures de l'Amoco Cadiz. Thèse Doct. Etat, Sci. nat., Univ. Pierre \& Marie Curie, Paris

Dauvin, J. C. (1988). Rôle du macrobenthos dans l'alimentation des poissons démersaux vivant sur les fonds de sédiments fins de la Manche occidentale. Cah. Biol. mar. 29: $445-467$

Dauvin, J. C. (1989). La méiofaune temporaire d'un peuplement subtidal de sédiment fin de la Manche occidentale. Echantillonnage, composition qualitative et quantitative. Ann. Inst. Océanogr. Paris 65: 37-55

Dauvin, J. C. (1990). Recrutement méiobenthique des principales espèces de polychètes et de mollusques bivalves d'un peuplement subtidal de sédiments fins de la Manche occidentale. Cah. Biol. mar. 31: 201-224

Dauvin, J. C. (1991). Effets à long terme (1978-1988) de la pollution de l'Amoco Cadiz sur la production de deux peuplements subtidaux de sédiments fins de la baie de Morlaix (Manche occidentale). In: Elliot, M., Ducrotoy, J.-P. (eds.) Estuaries and coasts: spatial and temporal intercomparisons. ECSA 19 Symposium. Olsen \& Olsen, Fredensborg, International Symposium series, p. 349-358

Dauvin, J C., Ibanez, F. (1986). Variations à long-terme (1977-1985) du peuplement des sables fins de la Pierre Noire (Baie de Morlaix, Manche occidentale): analyse statistique de l'évolution structurale. Hydrobiologia 142: $171-186$

De Wilde, P. A. W. J., Berghuis, E. M., Kok, A. (1984). Structure and energy demand of the benthic community of the Oyster Ground, central North Sea. Neth. J. Sea Res. 18: $143-159$

De Wilde, P. A. W. J., Berghuis, E. M., Kok, A. (1986). Biomass and activity of benthic fauna on the Fladen Ground (northern North Sea). Neth. J. Sea Res. 20: 313-323

De Wilde, P. A. W. J., Beukema, J. J. (1984). The role of the zoobenthos in the consumption of organic matter in the dutch Wadden Sea. Netherland Institute for Sea Research, Publ. Ser. 10: 145-158

Fallon, R. D., Newell, S. Y., Hopkinson, Ch. S. (1983). Bacterial production in marine sediments: will cell-specific measures agree with whole system metabolism? Mar. Ecol. Prog. Ser. 11 119-127

Gerlach, S. A. (1971). On the importance of marine meiofauna for benthos communities. Oecologia (Berl.) 6: 176-190

Gerlach, S. A. (1978). Food-chain relationships in subtidal silty sand marine sediments and the role of meiofauna in stimulating bacterial productivity. Oecologia (Berl.) 33: $55-69$

Grant, J., Hargrave, B. T (1987). Benthic metabolism and the quality of sediment organic carbon. Biol. Oceanogr. 4: $243-264$

Guidi, L. (1981). Etude expérimentale de la nutrition d'un amphipode épibenthique, Siphonoecetes dellavallei: relation qualité - quantité de la nourriture et ingestion. Thèse 3ème cycle, Océanographie biologique, Univ. Pierre \& Marie Curie, Paris
Hargrave, B. T (1970). The utilization of benthic microflora by Hyallela azteca (Amphipoda). J Anim. Ecol. 39: 427-437

Herndl, G. J., Faganeli, J., Fanuko, N., Peduzzi, P., Turk, V. (1987). Role of bacteria in the carbon and nitrogen flow between water-column and sediment in a shallow marine bay (Bay of Piran, Northern Adriatic Sea). P.S.Z.N. I: Mar. Ecol. 8: 221-236

Iturriaga, R. (1979). Bacterial activity related to sedimenting particulate matter. Mar. Biol. 55: 157-169

Jones, R., Henderson, E. W. (1987). The dynamic of nutrient regeneration and simulation studies of nutrient cycle. J. Cons. int. Explor. Mer 43: 216-236

Keizer, P. D., Gordon, D. C., Schwinghamer, G. R., Daborn, G. R., Ebenhoeh, W. (1987). Cumberland Basin ecosystem model; structure, performance and evaluation. Can. Tech. Rept. Fish. Aquat. Sci. 1547: 1-169

Kremer, J. N. Nixon, S. W. (1978). A coastal marine ecosystem. Simulation and analysis. Springer-Verlag, New York

Kuipers, B. R., De Wilde, P. A. W. J., Cwreuszberg, F. (1981) Energy flow in a tidal flat ecosystem. Mar. Ecol. Prog. Ser. 5: $215-221$

Lancelot, C., Billen, G. (1985). Carbon-nitrogen relationships in nutrient metabolism of coastal marine ecosystem. Adv. Aquat. Microbiol. 3: 263-321

Legovic, T. (1989). Predation in food webs. Ecol. Modelling 48: $267-276$

Levinton, J. S., Bianchi, T S., Stewart, S. (1984). What is the role of particulate organic matter in benthic invertebrate nutrition? Bull. mar. Sci. 35: 270-282

Loo, L.-O., Rosenberg, R. (1989). Bivalve suspension-feeding dynamics and benthic-pelagic coupling in an eutrophicated marine bay. J. exp. mar. Biol. Ecol. 130: 253-276

McIntyre, A. D., Munro, A. L. S., Steele, J. H. (1970). Energy flow in a sand ecosystem. In: Steele, $J \mathrm{H}$. (ed.) Marine food chains. Oliver and Boyd, Edinburgh, p. 19-31

Meyer-Reil, L.-A. (1987). Seasonal and spatial distribution of extracellular enzymatic activities and microbial incorporation of dissolved organic substrates in marine sediments. Appl. environ. Microbiol. 53: 1748-1755

Meyer-Reil, L.-A., Bölter, M., Dawson, R., Lieberzeit, G., Szwerinsky, H., Wolter, K. (1980). Interrelationships between microbiological and chemical parameters of sandy beach sediments, a summer aspect. Appl. environ. Microbiol. 39: 797-802

Navarro, J. M., Winter, J. E. (1982). Ingestion rate, assimilation efficiency and energy balance in Mytilus chilensis in relation to body size and different algal concentrations. Mar. Biol. 67: 255-266

Nedwell, D. B. (1987). Distribution and pool sizes of microbialy available carbon in sediment measured by microbiological assay. FEMS Microbiol. Ecol. 45: 47-52

Newell, R. C., Moloney, C. L., Field, J G., Lucas, M. I., Probyn, I A. (1988). Nitrogen models at the community level: plant-animal-microbe interactions. In: Blackburn, T H., Sorensen, J. (eds.) Nitrogen cycling in coastal marine environments. John Wiley and Sons Ltd., New York, p. 379-414

Newell, R. I. E., Bayne, B. L. (1980). Seasonal changes in physiology, reproductive condition and carbohydrate content of the cockle Cardium (= Cerastoderma edule) Bivalvia, Cardiidae. Mar. Biol. 56: 11-19

Pace, M. L., Glasser, J. E., Pomeroy, L. R. (1984). A simulation analysis of continental shelf food webs. Mar. Biol. 82: $47-63$

Radford, P. J. (1979). Some aspects of an estuary ecosystem model. GEMBASE. In: Jorgensen, S. E. (ed.) State-of-the- 
art in ecological modelling. Proceedings of the ISEM conference on ecological modelling, Copenhague, 1978. International Society for Ecological Modelling, p.: 301-322

Rees. H. L. (1983). Pollution investigation off the North East coast of England: community structure, growth and production of benthic macrofauna. Mar. environ. Res. 9: 61-110

Riaux-Gobin, C., Douchement, P., Tréguer, P. (1989). Microphytobenthos de deux sédiments subtidaux de Nord Bretagne. III Relations avec les sels minéraux azotés de l'eau interstitielle et deux facteurs hydroclimatiques. Hydrobiologia 178: 11-20

Rowe, G. T., Theroux, R., Phoel, W., Wilke, R., Koschoreck, D., Whitledge, T. E., Falkowski, P. G., Fray, C. (1988). Benthic carbon budgets for the continental shelf south of new England. Cont. Shelf Res. 8: 511-527

Salomon, J. C., Breton, M. (1987). Ferme aquacole en baie de Morlaix. Etude de courant et de dispersion dans le secteur compris entre l'île de Batz et la pointe de Primel. Rapport IFREMER, Centre de Brest

Schwinghamer, P., Hargrave, B., Peer, D., Hawkins, C. M. (1986). Partitioning of production and respiration among size groups of organisms in an intertidal benthic community. Mar. Ecol. Prog. Ser. 31: 131-142

Silvert, W. (1991). Experiments in benthic modelling. In: Herman P. M. J., Heip C. H. R. (eds.) Modelling the benthos: report of the COST 647 workshop. Yerseke 20-22 March 1991 Delta Institute for Hydrobiological Research, Yaseke, Communication 538: 175-188

Silvestre, G. (1990). Preliminary trophic model of the coastal fishery resources of Brunei Darussalam, South China Sea. Comm. Meet. Int. Counc. Explor. Sea C.M.-ICES L: 41, Sess. Q. 1-12

Sournia, A., Birrien, J. L., Douvillé, J. L., Klein, B., Viollier, M. (1987). A daily study of the diatom spring bloom at Roscoff (France) in 1985. I. The spring bloom within the annual cycle. Estuar. coast. Shelf Sci. 25: 355-367

Steele, J. H. (1974). The structure of marine ecosystems. Harvard Univ. Press, Cambridge

Tenore, K. R., Dunstan, W. M. (1973). Comparison of feeding and biodeposition of three bivalves at different food levels. Mar. Biol, 21. 190-195

Tenore, K. R., Gopalan, U. K. (1974). Feeding efficiencies of the polychaete Nereis virens cultured on hard clam tissue and oyster detritus. J. Fish. Res. Bd Can. 31. 1675-1682

Tenore, K. R., Cammen, L., Findlay, S. E. G., Phillips, N. (1982). Perspectives of research on detritus: do factors controlling the availability of detritus to macro-consumers

This article was submitted to the editor depend on its source. J. mar. Res. 40:473-490

Thingstad, T. F. (1987). Utilization of N, P, and organic C by heterotrophic bacteria. I. Outline of chemostat theory with a consistent concept of 'maintenance' metabolism. Mar. Ecol. Prog. Ser. 35: 99-109

Van Duyl, F. C., Kop, A. J. (1990). Seasonal patterns of bacterial production and biomass in intertidal sediments of the western Dutch Wadden Sea. Mar. Ecol. Prog. Ser. 59: $249-261$

Vranken, G., Heip, C. (1986). Productivity of marine nematodes. Ophelia 26: $429-442$

Wafar, M. V M. (1981). Nutrients, primary production and dissolved and particulate organic matter in well mixed temperate coastal waters (Bay of Morlaix - western English Channel). Thèse 3ème cycle, Océanographie Biologique, Université P. \& M. Curie, Paris

Wafar, M. V. M., Le Corre, P., J. L. Birrien (1983). Nutrient and primary production in permanently well-mixed temperate coastal waters. Estuar. coast. shelf Sci. 17: 431-446

Warwick, R. M., Joint, I. R., Radford, P. J. (1979). Secondary production of the benthos in an estuarine environment. In: Jeffries, R. L., Davy, A. J. (eds.) Ecological processes in coastal environment. Blackwell, London, p. 429-450

Westrich, J. T., Berner, R. A. (1984). The role of sedimentary organic matter in bacterial sulfate reduction: the $\mathrm{G}$ model tested. Limnol. Oceanogr. 29: 236-249

Widdows, J., Bayne, B. L. (1971). Temperature acclimatation of Mytilus edulis with reference to its energy budget. J. mar. biol. Ass. U.K. 51. 827-843

Wiegert, R. G. (1975). Mathematical representation of ecological interactions. In: Levin, S. A. (ed.) Ecosystem analysis and prediction. Proceedings of the SIAM. SIMS conference. Philadelphia Society of Industrial and Applied Mathematics, Alta, Utah, p. 43-53

Wiegert, R. G., Christian, R. R., Wetzel, R. L. (1981). A model view of the marsh. In: Pomeroy, R., Wiegert, R. G. (eds.) Ecology of a saltmarsh. Springer-Verlag. New York, p. $183-218$

Williams, P. J. leB. (1984). Bacterial production in the marine food chain: the emperor's new suit of clothes? In: Fasham, M. J. R. (ed.). Flows of energy and matter in marine ecosystems, theory and practice. NATO conference series Plenum Press, New York, p. 271-299

Zeitzschel, B. (1979). Sediment water interactions in nutrient dynamics. In: Tenore, K. R., Coull, B. C. (eds.) Marine benthic dynamics. University of South Carolina Press, Columbia, p. 195-218

Manuscript first received: July 9, 1991

Revised version accepted: December 23, 1991 